\title{
How social is Islamic banking?
}

\author{
M. LUTHFI HAMIDI $I^{t, t}$ AND ANDREW C. WORTHINGTON \\ ${ }^{\dagger}$ Sekolah Tinggi Ekonomi Islam (SEBI), \\ Jawa Barat, Indonesia \\ mluthfi.hamidi@griffithuni.edu.au \\ ${ }^{*}$ Department of Accounting, Finance and Economics \\ Griffith University \\ Nathan, QLD 4111, Australia \\ a.worthington@griffith.edu.au \\ * Corresponding author
}

Purpose - Outline the argument for social outcomes as an objective for Islamic banks and investigate whether social failure exists in Islamic banking in Indonesia by assessing it against this performance dimension.

Design/methodology/approach - Content analysis of the annual reports of a sample of 12 Islamic commercial banks, seven Islamic banking units, and seven Islamic rural banks operating in Indonesia. The social outcomes to be measured employ the social objectives and disclosure measures from the prevailing literature, combined with the Kinder, Lydenberg, Domini Research \& Analytics index of corporate social performance, the United Nations' 17 Sustainable Development Goals and five Environment Social Governance Scorecards developed by Oikocredit, a global cooperative and social investor group.

Findings - Social failure evident in all Islamic rural banks and half of all Islamic commercial banks, but in only one of the seven Islamic bank units where most banks appear to pursue social outcomes at the accommodative level (accepting and doing all that is required). A social outcome-weighted asset formulation reveals Islamic banking has improved in meeting its social objectives over time, but sometimes at the cost of other objectives relating to the environment and customers.

Research limitations/implications - Single-country context for analysis and limited period of analysis given rapid growth of industry and less stringent reporting requirements in the past.

Practical implications - Islamic banking in Indonesia needs to continue to improve its social outcomes, particularly in relation to the environment and customer benefits.

Social implications - Emphasis on banking supervisory bodies to regulate and provide incentives for the industry to address the social issues upon which consumer support, industry efforts and regulation draws.

Originality/value - Few existing studies investigate the social dimension of Islamic banking, not least in Indonesia. Novel quantitative and qualitative application of content analysis.

Keywords: Islamic banking; social banking; social responsibility.

Article Classification: Research Paper 



\section{Introduction}

Islamic banking, or banking that adheres to Shar'iah (or Islamic law), is generally considered to be more socially oriented than conventional banking (Asutay and Harningtyas, 2015; Haniffa and Hudaib, 2007), with the oft-quoted objective of promoting a just, fair, and balanced society. In reality, however, Islamic banking has long been criticised as demonstrating 'social failure' given its small positive impact on desirable social outcomes where it is practiced (Asutay, 2007; Mohd Nor et al., 2016). Further, it is often argued that Islamic banking as a whole is experiencing a progressive refocusing from achieving, among other things, improvements in falah (human wellbeing) to profit maximisation (Abdul-Baki and Uthman, 2017), as typically found in most conventional banks.

In investigating the social dimension of Islamic banking, some studies assess corporate social responsibility (Amran et al., 2017; Hassan and Harahap, 2010; Mallin et al., 2014) and others social and ethical reporting (Haniffa and Hudaib, 2007; Kamla and G. Rammal, 2013; Maali et al., 2006). Yet others consider the inclusion of social considerations into performance measures based on Maqasid al-Shari'ah (or higher objectives as they relate to human wellbeing) (Asutay and Harningtyas, 2015; Mohamad et al., 2016; Mohammed et al., 2008). The results mostly find that Islamic banking by itself has apparently little impact on social outcomes, at least beyond that of comparable conventional banks in the same circumstances.

As a means of further informing this debate, we examine the perceptions of social failure in Islamic banking. Using a case study approach of Islamic banking in a single country (Indonesia), we first theoretically identify the desired social outcomes of Islamic banking. These include social programs and policies aimed at managing social concerns among stakeholders. We define social outcomes here as the observable results of the implementation of Islamic banking social objectives. Within a broad Islamic banking framework (and Islamic economics more generally) these comprise promoting a just, fair, and balanced society by reinforcing social solidarities and through strengthening values (Naqvi, 2016; Tripp, 2006).

In terms of specific outcomes, Hamidi and Worthington (2017) highlight the actual social actions of Islamic banking such as the delivery of qardh al-hasan (benevolent loans), the conduct of charity through zakat (alms giving), and avoiding the effects of any potentially harmful financing on the environment and society. Using this approach, we measure the social responsiveness of Islamic banking and determine the stated attitude of a sample of banks toward a social orientation ranging from denying to anticipating responsibility. This yields the 
actual social dimension level of individual banks and allows us to assess whether these Islamic banks are meeting their social commitments.

The analysis differs from previous studies at least in three aspects. First, in terms of assessing social responsibility, with the exception of Kamla and G. Rammal (2013), previous studies in this area employ content analysis with a quantitative dimension relating to the use of certain words or the number of sentences or pages. This is a mere dichotomous approach to the assessment of performance constructs, whereby a construct will be given a score of one if present in the text, otherwise zero (Amran et al., 2017; Haniffa and Hudaib, 2007; Mallin et al., 2014). By itself, it would be better to balance this with qualitative evaluation, as in the present study.

Second, existing analyses of social disclosure by Islamic banks largely employ the guidelines of the Accounting and Auditing Organization for Islamic Financial Institutions (AAOIFI) - a not-for-profit organization established to maintain and promote Shari'ah standards for Islamic banking. For instance, Haniffa and Hudaib (2007) and Hassan and Harahap (2010) usefully address Islamic bank social performance relating to strategy, governance, products, community, employment, the environment, and R\&D. However, it is strange that these measures omit, say, the piousness and devoutness of Islamic banking management and staff. For this reason, we extend the prevailing framework to include religiosity as this may profoundly influence the attitude of an Islamic bank toward its social responsibilities (Ibrahim et al., 2008; Ramasamy et al., 2010).

Finally, existing studies have been very much limited in scope, with most considering social dimensions in only full-blown Islamic commercial banks (Bank Umum Shari'ah in Indonesia). In this analysis, along with 12 Islamic commercial banks, we additionally consider the social performance dimensions of seven Islamic business units (Unit Usaha Shari'ah), and seven Islamic rural banks (Bank Pembiayaan Rakyat Shari'ah). This provides a much more comprehensive account of how social objectives and outcomes vary across Islamic banking in all its various institutional forms.

The remainder of the paper is structured as follows. The second section provides the background of Islamic banking and its social objectives. The third section discusses the methodology and the fourth section presents the findings. The final section concludes. 


\section{Social Objectives in Islamic Banking}

\section{Islamic banking}

Islamic banking is a form of banking that conforms or complies with Shari'ah (or Islamic law). Perhaps its most commonly known feature is the prohibition of riba (the charging of interest or usury) (Chapra, 2007; Chong and Liu, 2009). Another is the promotion of profit-and-loss sharing (PLS) in which it is stipulated that the earning of profit should be based on actual economic activity (Zineb and Bellalah, 2013) and that borrowers alone should not bear risk, as a means to promote equity and justice in society (Khan, 2010). Under PLS, there are several different financing contracts available, including mudharabah (a partnership contract, wherein one side provides capital to a partner) and musyarakah (joint ventures). The expectation is that mudharabah and musyarakah develop actual businesses, and thereby function as a means of absorbing unemployment, creating future business opportunities, and protecting Islamic banking from risky financial engineering as social objectives. This is also the most important Islamic banking product, with up to 90 percent of Islamic banking financing in some countries relying on these debt-like contracts (Hasan et al., 2018; Vogel and Hayes, 1998).

Many also know that Islamic banking avoids haram (sinful) business, including the financing of firms that produce and sell alcohol, drugs and intoxicants, pork-related products, armaments, and indecent entertainment (Zineb and Bellalah, 2013). Finally, Islamic law, and by implication, Islamic banking, prohibits gharar (uncertainty and excessive risk that may cause injustice to other parties) and maisir (gambling and speculation). These help ensure that businesses that are the customers of Islamic banks, as well as the banks themselves, act on an ethical basis and avoid injustice by permitting no allowance for asymmetric information that could be potentially harmful for the parties in banking relationships (Zineb and Bellalah, 2013).

Alongside these products and services, other Islamic banking services include zakat and qardh al-hasan, whose purpose is to support the needy and alleviate poverty, all good social objectives. Nonetheless, Islamic banking still faces accusations that it has failed to deliver on its commitment to social responsibility. This failure in demonstrating social ends seems to suggest Islamic banking particularly prioritises better-off customers and that the services of Islamic banks consequently have no significant impact on the lives of the more marginalised (Asutay and Zaman, 2009).

Moreover, given the need to accumulate profit to ensure long-term sustainability, Islamic banks are moving towards legal forms to meet their fiqh (jurisprudence) limitations, but 
increasingly ignoring their primary Shari'ah objectives (Nienhaus, 2011). As a result, there is not a full integration of the ethical dimension into existing banking practice (Mansour et al., 2015), suggesting Maqasid al-Shari'ah (the objectives of Islamic law) as the central guidance for delivering "benefits and preventing harm" may be undelivered in practice. This may mean that their social and developmental outcomes are difficult, if not impossible, to achieve.

\section{Social objectives in Islamic banking}

Tulsian and Pandey (2008) classified business objectives into four categories: economic, social, human, and national. They further assert that the major social objectives include: (1) the supply of the desired quality of products; (2) the avoidance of antisocial and unfair trade practices; (3) the generation of employment; (4) the provision for the welfare of employees; (5) the avoidance of slums and pollution; and (6) contributing to the general welfare of society. Serving social objectives, rather than only maximizing profits, is also desirable in the banking industry. In particular, if banks fail to promote social welfare, some may come to see that regulation, including at the extreme as state-owned enterprises, are an alternative way to address market failure and a potentially better way to contribute to economic development and societal welfare.

In relation to social objectives, Islamic scholars divide into two opposing groups on the role of social objectives in Islamic banking. A relative few believe that Islamic banks should operate as normal business entities as long as their operations comply with Shari'ah (Lewis and Algaoud, 2001). This may mean, for instance, a reliance on zakat as the main social contribution, but only if these do not put owner funds at risk. In contrast, the majority of Islamic scholars consider that Islamic banking should aim at supporting and encouraging an economic system aimed at promoting a just, fair, and balanced society (Naqvi, 2016). In this way, any economic interaction in society is to "...increase the sum of public happiness, whilst reinforcing social solidarities and strengthening their values” (Tripp, 2006, p. 119). In a similar way, Al-Zuhayli (2003, p. 250) argued “...the primary goal of Islamic financial institutions is not profit-making, but the endorsement of social goals of socioeconomic development and the alleviation of poverty."

To realize these values, Islamic banks should include these tenets in their daily activities, and not place an emphasis solely on financial profit, but also distributive justice and fulfilling their societal obligations (Taqi-Usmani, 2002). Furthermore, Islamic banking should at least be more socially responsible than conventional banks (Asutay and Harningtyas, 2015; Haniffa and Hudaib, 2007). As a result, Kamel (1997) argued that Islamic goals should include 
objectives relating to economic development, the creation of value-added, more exports and fewer imports, job creation, the rehabilitation of the incapacitated, and the training of others.

To date, this strong view of the social responsibility of Islamic has found legislative support in just a few countries, including Indonesia and Jordan (Hamidi and Worthington, 2017). In evidence, in Indonesia the Undang-undang Republik Indonesia Nomor 21 Tahun 2008 tentang Perbankan Syariah (Islamic Banking Acts) explicitly encourages Islamic banks to perform a social function. Similarly, Law No. 28 Year 2000 Banking Law in Jordan requires that Islamic banks not only provide banking services, but also help revive social solidarity and provide qard al-hasan as a public interest.

\section{Corporate and social responsibility (CSR) in Islamic banking}

The interrelation between business as a whole and society has been observed for decades, what some refer to as corporate social responsibility (CSR), being “... a concept whereby companies integrate social and environmental concerns in their business operations and in their interaction with their stakeholders on a voluntary basis (Commission of the European Communities, 2001). On this, Friedman (1970, pp. 2-6) made a distinction between the social responsibility of individuals and that of business:

If he wishes to spend his money on such purposes, that is his right and I cannot see that there is any objection to his doing so... There is one and only one social responsibility of business-to use its resources and engage in activities designed to increase its profits so long as it stays within the rules of the game, which is to say, engages in open and free competition without deception or fraud.

In contrast, Steiner (1975) asserted that the concept of CSR covers not only economic aspects of business, but also legal behaviour and voluntary activity. As a guide, Frederick (1978) introduced corporate social responsiveness $\left(\mathrm{CSR}_{2}\right)$ as a means of measuring the response of corporates to social pressure, ranging from no response (do nothing) to proactive (do much). Later, Carroll (1979) described social responsibility as including economic, legal, ethical, and discretionary responsibilities and extended the concept of CSR to corporate social performance (CSP) by proposing a three-dimensional conceptual model consisting of social responsibility, social responsiveness, and social issues. Wartick and Cochran (1985) and later Clarkson (1995) then classified $\mathrm{CSR}_{2}$ into four degrees of social response, namely, reactive, defensive, accommodative, and proactive (or RDAP).

Carroll (1979) further differentiated between social and stakeholder issues because 
corporations and their managers are sometimes more willingly to engage with stakeholders than with society, so proposed the evaluation of CSP using a stakeholder framework. Graves and Waddock (1994) subsequently suggested the use of a CSP index, using data provided by Kinder, Lydenberg, Domini Research \& Analytics (KLD). At the time, KLD evaluated CSP across eight dimensions including community relations, employee relations, environment, product, treatment of women and minorities, military contracts, nuclear power, and involvement in South Africa.

Aguilera et al. (2007) argued that stakeholders support CSR for three main reasons: (1) instrumental (self-interest driven), (2) relational (group member relationship), and (3) moral (moral beliefs and ethical values). In relation to the moral motive, a few studies consider the role of religion in business. Ibrahim et al. (2008) found that religiousness has a significant impact on the economic, ethical, and responsibility of business. Elsewhere, Ramasamy et al. (2010) suggested that there is direct relation between consumer religiosity and business CSR.

As a rule, CSR from an Islamic perspective somewhat differs from the Western viewpoint. Dusuki (2005) argued that Islamic CSR draws on the concept of falah (literally success), as demonstrated by the achievement of material wellbeing in the material world and eternal life in the hereafter. Others offer CSR based on the Islamic principle of Tawhid. This requires a belief in Allah as the one and only God by surrendering all human actions to His commands (Basah and Yusuf, 2013; Zain et al., 2014). From this perspective, as God is the Creator, Owner, and Sustainer of all creatures and the universe, all human behaviour, attitudes, and activities, including business should be accountable before Allah.

Only a few existing studies investigate the operation of CSR in Islamic banking. Maali et al. (2006) employed a disclosure index to assess 29 Islamic banks operating in 16 countries and revealed that social reporting is much less than that expected, with only those banks paying zakat demonstrating consistently good social disclosure. Elsewhere, Haniffa and Hudaib (2007) examined the ethical identity of seven Islamic banks and found that these failed to meet the ideal Islamic ethical identity in at least four dimensions: commitment to society, disclosure of corporate vision and mission, role in managing zakat, charity, and benevolent loans, and top management information.

For its part, Islamic banking may contribute to reducing poverty in society both directly and indirectly. Islamic banks can use, for example, their own funds to support programs and initiatives aimed at developing human resources and providing institutional capital, such as creating a scholarship or establishing a library. This effort will indirectly help poor people to gain education and in turn improve their knowledge and skills to obtain a better living. 
Alternatively, Islamic banking can directly allocate funds for a group-based lending approach, say, for women and the disadvantaged. BTPN Syariah (2018), a large Indonesian Islamic bank, uses this approach to finance around five million customers, almost all of whom are women and many are traditionally 'unbankable'.

Another possible route is through channelling. In this case, Islamic banks pool their funds in an Islamic rural bank (Bank Pembiayaan Rakyat Syariah or BPRS) and then BPRS acts as an agent to disburse these funds to end users along social lines. Some leading Islamic banks in Indonesia, including Bank Muamalat, Bank Syariah Mandiri and Bank Danamon Syariah, have applied this method. Among the benefits are that they can reduce cost (no need for human resources to administrate the transactions and to monitor the financing) and more effectively achieve their social objectives with minimal disruption to their own business operations. Lastly, Islamic banks can also maximise through social aims through conventional social features such as zakat (obligatory alms giving), qardh al-hasan (benevolent loans) and cash waqf (endowment in the form of money). The purpose of this paper is to assess these disparate efforts.

\section{Methodology}

For our analysis, we use data on Indonesian Islamic banks derived from their published annual reports. A typical annual report in Indonesia comprises five main parts: (1) company profile, (2) performance highlights, (3) management report and analysis, (4) good corporate governance information, and (5) corporate social responsibility. We use all of these parts to determine and assess their social outcomes. Where information is unavailable in the annual reports (mostly for very small banks), following Kamla and G. Rammal (2013) and Mallin et al. (2014) we use each institution's website to obtain the details on their financial and other social activities, along with the financial reports submitted to the Indonesian Financial Services Authority

Based on the Undang-Undang Republik Indonesia Nomor 21 Tahun 2008 tentang Bank Shariah (Islamic Banking Act), Islamic banks in Indonesia also take one of three possible forms. These are an Islamic commercial bank or Bank Umum Syariah (BUS) (a fully-fledged Islamic bank), an Islamic banking unit or Unit Usaha Syariah (UUS) (where a conventional bank opens an Islamic banking window), and an Islamic rural bank or Bank Pembiayaan Rakyat Syariah (BPRS). There are 26 banks in our sample, comprising 13 BUS, 7 UUS, and 7 BPRS. This sample is significantly larger than those in other work on Indonesian Islamic banks, 
including Haniffa and Hudaib (2007) with just seven banks and Kamla and G. Rammal (2013) with 19 banks and with total assets of IDR276.7 trillion, they represent about 76 percent of total Indonesian Islamic bank assets of IDR365.6 trillion.

The BUS sample comprises Bank Muamalat Indonesia, Bank Victoria Syariah, BRI Syariah, BJB Syariah, BNI Syariah, BNI Syariah, Bank Syariah Mandiri, Bank Mega Syariah, Bank Panin Dubai Syariah, Bank Panin Dubai Syariah, Bank Syariah Bukopin, BCA Syariah, Bank Maybank Syariah Indonesia and BTPN Syariah. The seven UUS are the largest of the total 20 UUS operating in Indonesia and are UUS Danamon, UUS Bank Kalbar, UUS Bank DIY, UUS BPD Jateng, UUS CIMB-Niaga, UUS BPD Sumbar, and UUS Permata. Lastly, we also only select the seven largest BPRS, comprising BPRS HIK Parahyangan, BPRS Bhakti Sumekar, BPRS Amanah Ummah, BPRS Al-Ma'soem, BPRS Dinar Ashri, BPRS HIK Bekasi, BPRS Suriyah.

We employ content analysis to observe the social outcomes of these Islamic banks in their various forms. For the most part, content analysis analyses textual data, but can also be used in relation to images, maps, and numerical contents. The challenging part of content analysis is to select and develop categories so that the content can be appropriately grouped and classified. Traditionally, content analysis is most appropriate for revealing new phenomena, so researchers specify categories collected from the data. However, we use directed content analysis and this requires theory to identify the key concepts or categories needed for the initial coding (Potter and Levine-Donnerstein, 1999).

We identify the categories from the prevailing Islamic banking literature, particularly in relation to social objectives and disclosure (Haniffa and Hudaib, 2007; Hassan and Harahap, 2010; Maali et al., 2006; Rashid et al., 2013). We augment these using the KLD index of corporate social performance (Graves and Waddock, 1994; Mattingly and Berman, 2006), the 17 United Nations Sustainable Development Goals (SDGs) and the five Environment Social Governance (ESG) Scorecards developed by Oikocredit (2017), a worldwide cooperative and social investor group, as depicted in Figure1.

\section{$<$ INSERT FIGURE 1 HERE $>$}

Drawing on Figure 1, we extract six distinct dimensions reflecting the social objectives of Islamic banks, each including a number of constructs. The first dimension is religiosity which contains four constructs: (a) zakat; (b) qardh al-hasan; (c) riba; and (d) encouraging spirituality. The second dimension is environmental, which we classify into three constructs: 
(e) preserving and contributing to environment; (f) managing a green office; and (g) managing green financing. The third dimension is social ends consisting of three constructs: (h) engagement in the community in terms of education and training; (i) quality improvements; and (j) economic empowerment.

The fourth dimension is governance matters, comprising four constructs: $(\mathrm{k})$ vision and mission; (1) preventing corruption and fraud; (m) handling customer complaints; (n) ethics and staff compliance. The fifth dimension concerns how Islamic banks manage their employees, and includes the three constructs of (o) rewards; (p) equal work opportunity; and (q) training and education for employees. The sixth and final dimension addresses customer orientation and relates to the constructs of $(\mathrm{t})$ serving unserved areas; (s) having diversified financial products, particularly for women and the disadvantaged; and (s) giving discounts for customers. In total, there are six dimensions across 21 constructs. The Appendix explains how we use keywords to first identify and then code each of the constructs.

While well established, content analysis is not without its challenges, given reliability issues may arise due to the vagueness of meanings or definition, while problems of validity concern the extent the result is consistent with the existing theory. To enhance reliability, we use three coders to score the research constructs. To improve validity, we use the categories and definitions from both the Islamic banking and corporate social performance literatures. The scoring of constructs uses a dichotomous and quantitative approach. To assess social outcomes, we employ an equal-weighted index to measure the score for each bank under each dimension:

$$
\frac{\sum_{t=1}^{n_{j}} X_{i j}}{n_{j}}
$$

where $n_{j}$ is the number of items or constructs disclosed by the $j$ th bank, with $n_{j}=20$ and where $X_{\mathrm{ij}}=2$ if the $i$ th construct is both qualitative and quantitative, $X_{i j}=1$ if the construct is only qualitative, and $X_{i j}=0$ if neither. Consider construct (1) preventing corruption and fraud as an example. We first search the annual reports using the keywords of 'corruption' and 'fraud'. We then code this construct as follows. If a bank has no explicit concept to deal with corruption or fraud, it scores zero; if a bank has an explicit concept to deal with corruption or fraud, it scores one; and if a bank has an explicit concept to deal with corruption or fraud, establishes an antifraud division and reports the fraud, it scores two. 
To rank the social responsiveness of each bank, we use the four-category rating scale of reactive, defensive, accommodative, and proactive (RDAP) as introduced by (Carroll, 1979; Wartick and Cochran, 1985; Clarkson, 1995), and modified by Hamidi and Worthington (2018), as shown in Table I.

\section{$<$ INSERT TABLE I HERE $>$}

Finally, to investigate whether there is social failure across Indonesian Islamic banks overall; we use a social outcome-weighted asset formulation as follows:

$$
\bar{x}=\frac{\sum_{i=1}^{n} x_{i} w_{i}}{\sum_{i=1}^{n} w_{i}}
$$

where $\bar{x}$ is social outcome-weighted assets, $x_{i}$ is the value of social outcome $i$ and $w_{i}$ is the asset weighting of $x_{i}$. If banks underperform, indicated by a rating of either reactive (R) or defensive (D), then we consider social failure is evident.

\section{Results}

Table II provides the content analysis results for 2015 and 2016, as drawn from the most recent (sometimes only) data available. As shown, all BUS have improved their social outcome ratings from 2015 to 2016, except for BMI and BCA Syariah. The best social outcome performance is BNI Syariah with achievements of 72.5\% and 77.5\% in 2015 and 2016, respectively, followed in second and third place by BSM with 70\% and 72.5\% and BTPN Syariah with $57.5 \%$ and $72.5 \%$. The worst performing BUS is Bank Victoria Syariah with a score of only $12.5 \%$ in 2015 , albeit with the largest increase (80\%) to $22.5 \%$ in 2016 . Overall, of the 12 BUS in 2015, only five are performing in terms of social outcomes, that is, with ratings of either accommodative (A) (accepting responsibility or doing all that is required) or proactive $(\mathrm{P})$ (anticipating responsibility and doing more than required). However, this is improving, such that by 2016, an addition two BUS are performing in terms of social outcomes.

\section{$<$ INSERT TABLE II HERE $>$}

Nonetheless, while the performance of the BUS in terms of social outcomes continues to increase overall, there are some neglected dimensions. For example, Table III shows that the environmental dimension has only an average achievement of just $43 \%$ across the 12 BUS in 
2016. While nearly half of the BUS give attention to environmental awareness and make serious efforts to enhance green offices, they mostly fail to provide green financing. This finding is consistent with Asutay and Harningtyas (2015) and Mallin et al. (2014) that Islamic banks tend to be less attentive to the environment, with Mallin et al. (2014) also revealing that the environment scores among the lowest of the several other dimensions under investigation. Possible ways Islamic banks could pay more attention to environmental matters including designing policy to assess financing based on environmental preferences and promoting their own environmental awareness such as using office equipment that reduces energy consumption and greenhouse gas emissions from the production of electricity, paper and photocopying toner. Islamic banks could also more actively involve themselves in protecting nature through the allocation of funds for green financing.

\section{$<$ INSERT TABLE III HERE $>$}

Another dimension severely unaddressed by the BUS is customer's benefits, scoring a very low social outcome of just $9.72 \%$. This indicates that the BUS in Indonesia ignore three key elements: serving unserved areas, creating financial products for disadvantaged groups, and rewarding customers with discounts. To serve remote areas, a few of these banks have engaged in a linkage strategy through microfinance, but only a few have particular services such as providing banking products to the poor. Furthermore, few banks give discounts to customers who want to speed up payments, while muqasah is almost non-existent. This is despite the National Syariah Council making a decision based on religious considerations (fatwa) Number: 23/DSN-MUI/III/2002 that it is lawful to provide a deduction from the payment obligation, as long as it is unstipulated in the contract.

In term of governance, and as shown in Table III, the BUS achieve a significant improvement from around $63 \%$ in 2015 to $71 \%$ in 2016. From all 12 BUS in 2015, only a single bank has no explicit concept to address fraud (Bank Victoria Syariah), although four banks (BRI Syariah, BJB Syariah, Bank Mega Syariah, BCA Syariah) explain their fraud concept, but without reporting how they actually execute it. The remaining banks (Bank Muamalat, BNI Syariah, Bank Syariah Mandiri, Bank Panin Syariah, Bank Bukopin Syariah, Maybank Syariah, and BTPN Syariah) present both the concept of fraud and prove its actual implementation. For instance, Bank Muamalat established an Anti-Fraud Division (AFD) in 2011. In 2015, AFD investigated two internal frauds conducted by permanent staff with potential losses of IDR100 million (Bank Muamalat, 2016). In the same year, the management 
of BNI Syariah identified two fraud cases committed by permanent staff and one by a nonpermanent employee, but while now settled, did not report the potential for loss (BNI Syariah, 2017).

In regards to religiosity, the average score is also quite good in the sense that most of the BUS payzakat (70.8\%) and distribute qardh al-hasan (91.6\%), but only a few campaign actively against riba (25\%) and promote spirituality in their daily business (33.3\%), hence the average is only about $55.2 \%$. Importantly, Islamic banks are not directly involved in the management of zakat. Instead, they will conventionally establish a subsidiary to represent their own Lembaga Amil Zakat (Zakat Management Board) or LAZ. For instance, BMI established Baitu Maal Muamalat, while BSM created LAZ BSM. Despite the ongoing domination of murabahah (debt-like contracts) over PLS products (mudharabah and musyarakah), the efforts of Islamic banks against riba is yielding positive results in Indonesia. For instance, total financing with PLS schemes increased from 35.65\% of all Islamic financing in December 2018 to $48.2 \%$ in December 2019 (Otoritas Jasa Keuangan, 2020).

That the BUS are focusing on zakat and qardh al-hasan is consistent with the results in Maali et al. (2006). From our analysis, nine of the 12 BUS in 2015 reported zakat payments in their annual reports (a score of 2), one (Bank Bukopin Syariah) explained zakat, but did not report the amount (a score of 1), while only two banks (Maybank Syariah and BTPN Syariah) did not identify nor report its implementation (a score of 0 ). In respect to governance, this has the highest average score (70.83\%) among the remaining dimensions, with the weakest part concerning vision and mission, with only one third of the BUS specifically identifying that they are eager to promote social and environmental goals, a finding similar to Haniffa and Hudaib (2007).

In stark contrast to the BUS, the Islamic banking units (UUS) appear significantly more focused, with only one failing to meet its social outcomes. Indeed, within a very short time, two UUS have moved from being accommodative (doing all that is required) to proactive (doing more than what is required). At first, this seems strange, as unlike the BUS, UUS are only Islamic banking windows operating within a conventional bank, not an entire institution dedicated to Islamic banking. The reason is likely that the UUS receive considerable benefit from this arrangement, with almost all CSR activities assumed by their conventional commercial banking parent, which typically perform much better than Islamic banks in terms of the environmental dimension.

However, both BUS and USS significantly underperform in terms of the customer benefit dimension, scoring just $9.72 \%$ and $11.9 \%$ in 2016 , respectively. Another interesting 
result is that religiosity in UUS (41.07\%) is lower than in the BUS (55.21\%). However, we somewhat expect this as a UUS campaigning strongly against say riba would be at odds with their commercial parent's largely interest-based operations. Furthermore, all UUS appear to ignore activities relating to spirituality with no evidence suggesting that they encourage regular prayer, sermons, or reciting the Qur'an.

Finally, in the case of the Islamic rural banks (BPRS), social outcome performance is unambiguously poor with their reactive ratings indicating that they either deny responsibility or pursue social outcomes less than that is required. This is somewhat ironic in that by design the expectation is that BPRS serve the poor and disadvantaged. There are a number of possibilities of why this is the case. First, BPRS publish their annual report as it is an obligatory based on Bank Indonesia Regulation PBI No. 7/47/PBI/2005. The report should consist of two specific parts: public information and the financial report. Unfortunately, most BPRS only meet the second, but not the first requirement. Consequently, some relevant information such as vision and mission, business development, strategies and policies taken by management may be missing from the information disclosed to the public.

Second, we expect that the social outcomes of BPRS are trivial because their financial performance is also quite poor. As Seibel (2008) argued, retired conventional bankers with weak Islamic banking skills manage many BPRS and this may weaken their core performance. However, this explanation might not fully fit, given the ratio of operational expense to operating profit (Rasio Biaya Operasional terhadap Pendapatan Operasional/BOPO) of BPRS is even smaller than that for the BUS, suggesting that the BPRS are relatively more efficient (Otoritas Jasa Keuangan, 2018). Third, the BPRS are very small when compared with the BUS and even the UUS, with the total assets of the some 101 BPRS being only about onesixth the size of the Bank Muamalat, a very large BUS. This small scale could severely hamper the BPRS in their efforts providing a particular social program or project. Another explanation is that BPRS face very fierce competition from conventional rural banks as well as commercial banks established to cater to rural users, such as Bank Rakyat Indonesia (BRI). Even if Muslim customers prefer to use Islamic microfinance services, in reality aspects such as easiness, service speed, and nearness may outweigh any religious motive.

Finally, we assess whether all Islamic banks in Indonesia fail in delivering social outcomes based on the SOWA assessment. Using the figures in TableIV, we conclude that in 2015, the observed banks fail as their SOWA is less than 50\%, thus achieving only a defensive rating (admitting responsibility but resisting it and doing the least that is required). However, this situation reverses in 2016, as some of BUS perform better with average social outcomes 
of $53.50 \%$. This result is consistent with Mallin's et al. (2014) findings. Nonetheless, all Indonesian Islamic banks of all forms continue to need to address their poor social performance in terms of the dimensions of environment and customer benefits.

\section{$<$ INSERT TABLE IV HERE $>$}

\section{Conclusion}

This paper identifies the social outcomes of three different types of Islamic banks in Indonesia in 2015-16, comprising all 12 Islamic commercial banks (BUS), seven Islamic business units (UUS), and the seven largest Islamic rural banks (BPRS). Employing content analysis, we confirm that social failure takes place in all BPRS, as the observed banks on average earn the lowest rating, namely, reactive (doing the least that is required). As a general rule, the UUS perform better than the BUS and the BUS better than the BPRS. However, all Islamic banks in Indonesia appear to pay little attention to the environment and customer benefits. In providing these findings, this paper contributes to the small but evolving literature on the ability of Islamic banks to deliver social outcomes.

There are three clear implications for institution, industry and regulatory policy. First, the Islamic banking sector needs to improve its social outcomes, particularly in relation to the environment and customer benefits. Failure to do so may result in a deterioration in support of ordinary Indonesians, especially the poor. This may feedback to Islamic banks in Indonesia, not just through banking markets, but also through political markets as the Indonesian government has identified the key role of Islamic banking in Indonesia's ongoing social and economic development. Second, the Islamic banking industry in Indonesia need to improve green financing and more seriously promote environmental awareness given these will improve both its own and the country's future sustainability. Finally, the banking supervisory bodies in Indonesia need to consider regulating and/or provide incentives for the banking industry to address these issues as there is a possible interplay with conventional banking regulation that also applies to Islamic banks. For instance, existing capital requirement regulations may neglect the risk arising from environmental concerns.

Of course, the analysis is not without its limitations, all of which suggest directions for future research. In particular, the content analysis in this study from a single country over just a two-year period may limit the generalisation of our findings. A cross-country analysis from a number of countries with Islamic banking industries may provide a better comparison, of 
which Malaysia would be ideal given its geographic location and other similarities with Indonesia. In addition, we could further investigate these findings from the perspective of stakeholders using say, surveys of Islamic bank customers, employees, managers and regulators, and this may complement the empirical results of this firm-driven content analysis.

\section{References}

Abdul-Baki, Z., and Uthman, A. B. (2017), "Exploring the "social failures" of Islamic banks: a historical dialectics analysis", Journal of Islamic Accounting and Business Research, Vol. 8 No. 3, pp.250-271.

Aguilera, R. V., Rupp, D. E., Williams, C. A., and Ganapathi, J. (2007), "Putting the S back in corporate social responsibility: A multilevel theory of social change in organizations", Academy of Management Review, Vol. 32 No. 3, pp.836-863.

Al-Zuhayli, W. (2003). Al-Fiqh al-Islami wa adillatuh (Islamic jurisprudence and its proofs) (M. A. El-Gamal, Trans.; Vol. 5). Dar al-Fikr al-Mouse, Damascus.

Amran, A., Fauzi, H., Purwanto, Y., Darus, F., Yusoff, H., Zain, M. M., Naim, D. M. A., and Nejati, M. (2017), "Social responsibility disclosure in Islamic banks: a comparative study of Indonesia and Malaysia", Journal of Financial Reporting and Accounting, Vol. 15 No. 1, pp.99-115.

Asutay, M. (2007), "Conceptualisation of the second best solution in overcoming the social failure of islamic finance: Examining the overpowering of homoislamicus by homoeconomicus", IIUM Journal in Economics and Management, Vol. 15 No. 2, pp.167-195.

Asutay, M., and Harningtyas, A. F. (2015), "Developing Maqasid al-Shari'ah index to evaluate social performance of Islamic banks: A conceptual and empirical attempt", International Journal of Islamic Economics and Finance Studies, Vol. 1 No. 1, pp.5-64.

Asutay, M., and Zaman, N. (2009), "Divergence between aspirations and realities of Islamic economics: A political economy approach to bridging the divide", IIUM Journal of Economics and Management, Vol. 17 No. 1, pp.73-96.

Bank Muamalat Indonesia. (2016), “Annual Report 2015: Embracing Change, Energizing Growth”, available at: https://www.bankmuamalat.co.id/uploads/hubungan investor/2 annual-report2015 20160623125348.pdf (accessed 20 July 2020)

Basah, M. Y. A., and Yusuf, M. M. (2013), "Islamic bank and corporate social responsibility (CSR)”, European Journal of Business and Management, Vol. 5 No. 11, pp.194-209.

BNI Syariah. (2017), "Annual report 2016: Commitment to realize the Hasanah lifestyle", available at: https://www.bnisyariah.co.id/Portals/1/BNISyariah/Perusahaan/Hubungan\%20Investor/Laporan\%20Ta hunan/PDF/Inggris/AR-BNI-Syariah-ENG-28-4-2017_Part1.pdf (accessed 20 July 2020).

BTPN Syariah. (2018), “Annual report 2018: Public”, available at: https://www.btpnsyariah.com/images/BTPNS_AR_2018 en.pdf (accessed 2 February 2020)

Carroll, A. B. (1979), “A three-dimensional conceptual model of corporate performance”, The Academy of Management Review, Vol. 4 No. 4, pp.497-505.

Chapra, M. U. (2007), “The case against interest: Is it compelling?”, Thunderbird International Business Review, Vol. 49 No. 2, pp.161-186.

Chong, B. S., and Liu, M.-H. (2009), “Islamic banking: interest-free or interest-based?”, Pacific-Basin Finance Journal, Vol. 17 No. 1, pp.125-144.

Clarkson, M. E. (1995), “A stakeholder framework for analysing and evaluating corporate social performance”, Academy of Management Review, Vol. 20 No. 1, pp.92-117.

Commission of the European Communities. (2001), "Promoting an European Framework for Corporate Social Responsibility", available at: http://eurlex.europa.eu/LexUriServ/LexUriServ.do?uri=COM:2001:0366:FIN:EN:PDF (accessed 26 July 2019). 
Dusuki, A. W. (2005), "Corporate social responsibility of Islamic banks in Malaysia: a synthesis of Islamic and stakeholders' perspectives”, [PhD Thesis, Loughborough University]. Loughborough. Available at: https://dspace.lboro.ac.uk/2134/7725 (accessed 25 December 2019).

Frederick, W. C. (1978), "From $\mathrm{CSR}_{1}$ to $\mathrm{CSR}_{2}$ the maturing of business-and-society thought", Business \& Society, Vol. 33 No. 2, pp.150-164.

Friedman, M. (1970), "The social responsibility of business is to increase its profits", New York Times Magazine, 13 September, pp. 32-33.

Graves, S. B., and Waddock, S. A. (1994), "Institutional owners and corporate social performance”, Academy of Management Journal, Vol. 37 No. 4, pp.1034-1046.

Hamidi, M. L., and Worthington, A. C. (2017), "Islamic banking plus social banking equals Islamic social banking: An equation in the making”, K. Jerzy (Ed.), Banking: Services, Opportunities and Risks. Nova Science Publishers, New York, pp.15-60.

Hamidi, M. L., and Worthington, A. C. (2018), "Islamic social banking: The way forward", Malaysian Journal of Economics, Vol. 52 No. 1, pp.195-207.

Haniffa, R., and Hudaib, M. (2007), "Exploring the ethical identity of Islamic banks via communication in annual reports”, Journal of Business Ethics, Vol. 76 No. 1, pp.97-116.

Hasan, H., Ali, S. S., and Muhammad, M. (2018), "Towards a maqasid al-shariah based development index", Journal of Islamic Business and Management, Vol. 8 No. 1, pp.20-36.

Hassan, A., and Harahap, S. S. (2010), "Exploring corporate social responsibility disclosure: the case of Islamic banks", International Journal of Islamic and Middle Eastern Finance and Management, Vol. 3 No. 3 , pp.203-227.

Ibrahim, N. A., Howard, D. P., and Angelidis, J. P. (2008), “The relationship between religiousness and corporate social responsibility orientation: are there differences between business managers and students?", Journal of Business Ethics, Vol. 78 No. 1-2, pp.165-174.

Kamel, S. (1997), Development of Islamic Banking Activity, Problems and Prospects. IDB Prize Winners' Lecture Series (12), IIIT, Jeddah.

Kamla, R., and G. Rammal, H. (2013), "Social reporting by Islamic banks: does social justice matter?", Accounting, Auditing \& Accountability Journal, Vol. 26 No. 6, pp.911-945.

Khan, F. (2010), “How 'Islamic'is Islamic banking?”, Journal of Economic Behavior \& Organization, Vol. 76 No. 3, pp.805-820.

Lewis, M. K., and Algaoud, L. M. (2001), Islamic Banking, Edward Elgar, Cheltenham.

Maali, B., Casson, P., and Napier, C. (2006), “Social reporting by Islamic banks”, Abacus, Vol. 42 No. 2, pp.266289.

Mallin, C., Farag, H., and Ow-Yong, K. (2014), "Corporate social responsibility and financial performance in Islamic banks", Journal of Economic Behavior \& Organization, Vol. 103, pp.S21-S38.

Mansour, W., Ben Jedidia, K., and Majdoub, J. (2015), "How ethical is Islamic banking in the light of the objectives of Islamic law?”, Journal of Religious Ethics, Vol. 43 No. 1, pp.51-77.

Mattingly, J. E., and Berman, S. L. (2006), "Measurement of corporate social action discovering taxonomy in the Kinder Lydenburg Domini ratings data", Business \& Society, Vol. 45 No. 1, pp. 20-46.

Mohamad, M. H. S., Ali, M. A., and Mohd Sharif, R. A. (2016), "Determinants of maqasid al-shari'ah-based performance measurement practices: The case of Malaysian Islamic banks", International Journal of Economics, Management and Accounting, Vol. 24 No. 1, pp.49-81.

Mohammed, M. O., Abdul Razak, D., and Md Taib, F. (2008), "The performance measures of Islamic banking based on the maqasid framework", paper presented at IIUM International Accounting Conference (INTAC IV), 24-25 June, Putra Jaya Marriott, Malaysia, available at: http://irep.iium.edu.my/10121/1/INTAC 4(accounting).Revised.pdf (accessed 15 December 2019).

Mohd Nor, S., Rahim, R. A., and Senik, Z. C. (2016), "The potentials of internalising social banking among the Malaysian Islamic banks", Environment, Development and Sustainability, Vol. 18 No. 2, pp.347-372. 
Naqvi, S. N. H. (2016), Perspectives on morality and human well-being: A contribution to Islamic economics. Kube Publishing, Markfield.

Nienhaus, V. (2011), "Islamic finance ethics and Shari'ah law in the aftermath of the crisis: Concept and practice of Shari'ah compliant finance”, Ethical Perspectives, Vol. 18 No. 4, pp.591-623.

Oikocredit. (2017), "Social and environmental performance report 2016: Strengthening people and planet", available at: https://www.oikocredit.coop/en/publications/social-and-environmental-performancereports-old (accessed 5 January 2019).

Otoritas Jasa Keuangan. (2016), "Sharia banking statistics", available at: https://ojk.go.id/en/kanal/perbankan/data-dan-statistik/statistik-perbankan-

syariah/Documents/Pages/Sharia-Banking-Statistic---December-2015/SPS\%20Des\%202015.pdf (accessed 21 August 2019).

Otoritas Jasa Keuangan. (2018), “Indonesia Banking Statistics 2018”, available at: https://www.ojk.go.id/en/kanal/perbankan/data-dan-statistik/statistik-perbankanindonesia/Documents/Pages/Indonesia-Banking-Statistic---September2018/Indonesia\%20Banking\%20Statistic\%20September\%202018.pdf (accessed 21 August 2019).

Otoritas Jasa Keuangan. (2020), "Sharia Banking Statistics December 2019”, available at: https://www.ojk.go.id/id/kanal/syariah/data-dan-statistik/statistik-perbankan-syariah/Pages/StatistikPerbankan-Syariah---Desember-2019.aspx (accessed 10 February 2020).

Potter, W. J., and Levine-Donnerstein, D. (1999), "Rethinking validity and reliability in content analysis", Journal of Applied Communication Research, Vol. 27 No. 3, pp.258-284.

Ramasamy, B., Yeung, M. C., and Au, A. K. (2010), “Consumer support for corporate social responsibility (CSR): The role of religion and values", Journal of Business Ethics, Vol. 91 No. 1, pp.61-72.

Rashid, M., Abdeljawad, I., Manisah Ngalim, S., and Kabir Hassan, M. (2013), "Customer-centric corporate social responsibility: A framework for Islamic banks on ethical efficiency”, Management Research Review, Vol. 36 No. 4, pp.359-378.

Seibel, H. D. (2008), "Islamic microfinance in Indonesia: The challenge of institutional diversity, regulation, and supervision”, SOJOURN: Journal of Social Issues in Southeast Asia, Vol. 23 No. 1, pp.86-103.

Steiner, G. A. (1975), Business and Society, Random House, New York.

Taqi-Usmani, M. (2002), An Introduction to Islamic Finance, Kluwer Law International, London.

Tripp, C. (2006), Islam and the Moral Economy: The Challenge of Capitalism, Cambridge University Press, Cambridge.

Tulsian, P., and Pandey, V. (2008), Business Organisation and Management, Pearson Education, New Delhi.

Vogel, F. E., and Hayes, S. L. (1998), Islamic Law and Finance: Religion, Risk, and Return, Kluwer Law International, Boston.

Wartick, S. L., and Cochran, P. L. (1985), "The Evolution of the corporate social performance model", The Academy of Management Review, Vol. 10 No. 4, pp.758-769.

Zain, M. M., Darus, F., Yusoff, H., Amran, A., Fauzi, H., Purwanto, Y., and Naim, D. A. (2014), “Corporate ibadah: an Islamic perspective of corporate social responsibility", Middle-East Journal of Scientific Research, Vol. 22 No. 2, pp.225-232.

Zineb, S., and Bellalah, M. (2013), "Introduction to Islamic Finance and Islamic Banking: From Theory to Innovations", M. Bellalah and O. Masood (Eds.), Islamic Banking and Finance, Scholars Publishing, Cambridge. 


\section{Figure1.}

Social performance indicators for Islamic banking

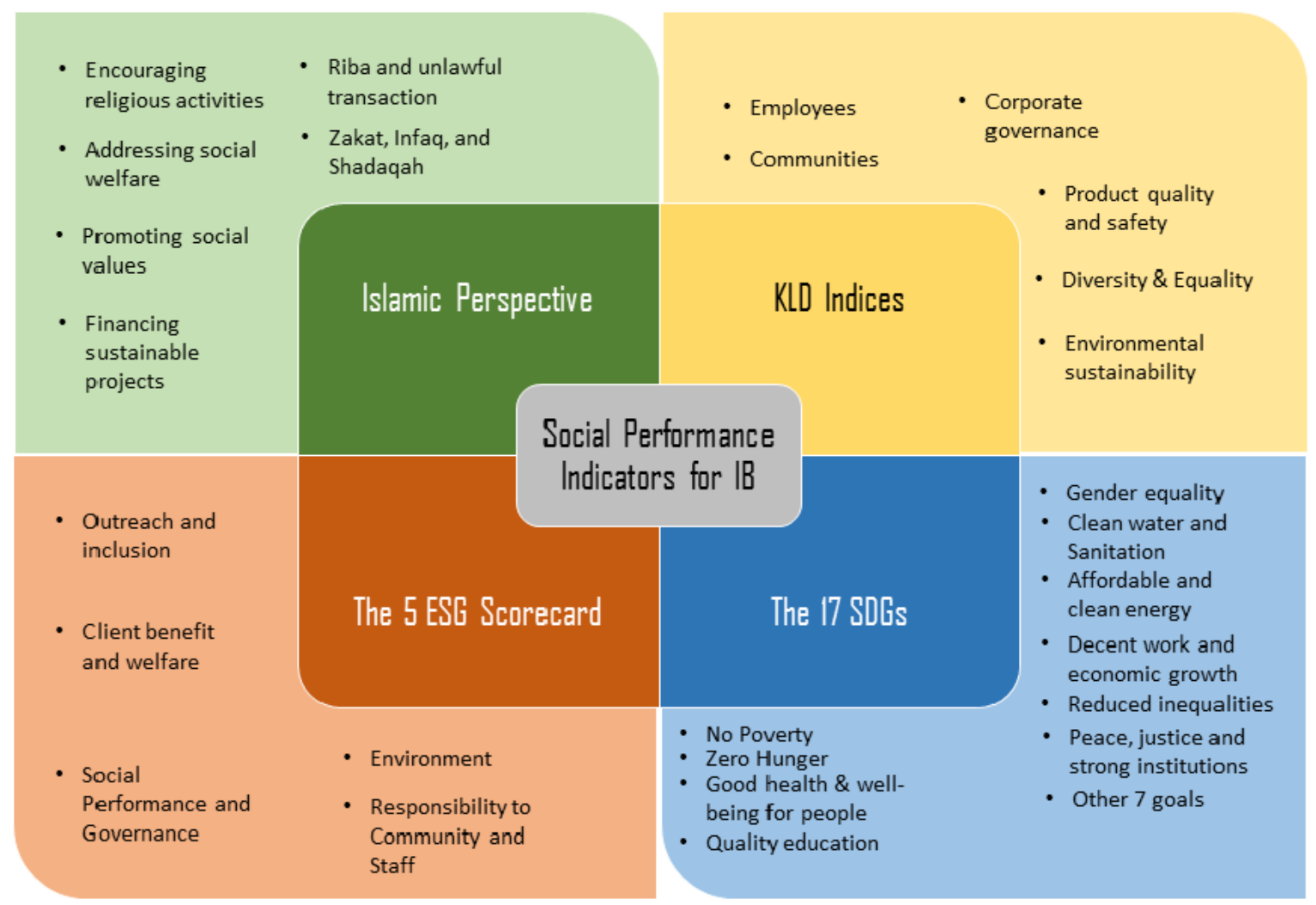

\section{Table I.}

RDAP scale for assessing social responsiveness

\begin{tabular}{clll}
\hline Achievement & \multicolumn{1}{c}{ Rating } & \multicolumn{1}{c}{ Posture or strategy } & \multicolumn{1}{c}{ Performance } \\
\hline $0-40 \%$ & Reactive & Deny responsibility & Doing less than required \\
$41-50 \%$ & Defensive & Admit responsibility but fight it & Doing the least that is required \\
$51-60 \%$ & Accommodative & Accept responsibility & Doing all that is required \\
$61-100 \%$ & Proactive & Anticipate responsibility & Doing more than is required \\
\hline
\end{tabular}




\section{Table II.}

Social outcome ratings

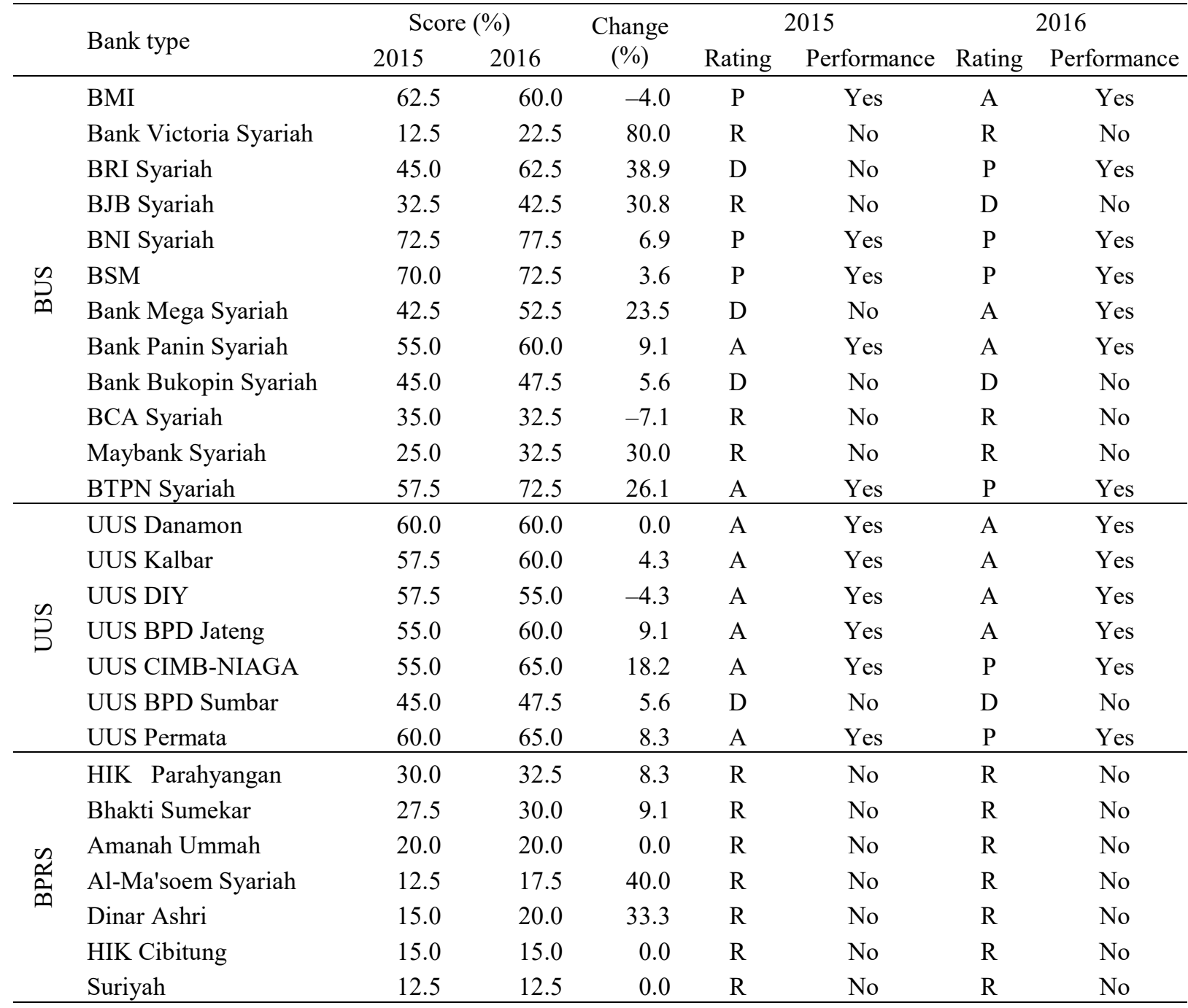

Notes: BUS (Bank Umum Syariah) or Islamic commercial bank; UUS (Unit Usaha Syariah) or Islamic bank unit; BPRS (Bank Pembiayaan Rakyat Syariah) or Islamic rural bank. $\mathrm{R}=$ Reactive, $\mathrm{D}=$ Defensive, $\mathrm{A}=\mathrm{Accommodative}$, $\mathrm{P}=$ Proactive

Table III.

Dimensions of social outcomes

\begin{tabular}{lccrrrrrrrr}
\hline & \multicolumn{3}{c}{2015} & \multicolumn{3}{c}{2016} & \multicolumn{3}{c}{ Change (\%) } \\
& BUS & UUS & BPRS & BUS & UUS & BPRS & BUS & UUS & BPRS \\
\cline { 2 - 10 } Religiosity & 52.08 & 37.50 & 29.17 & 55.21 & 41.07 & 28.13 & 6.00 & 9.52 & -3.60 \\
Environment & 15.28 & 69.05 & 0.00 & 43.06 & 59.52 & 0.00 & 181.8 & -13.80 & 0.00 \\
Social & 77.78 & 78.57 & 5.56 & 69.44 & 83.33 & 6.94 & -10.70 & 6.10 & 24.80 \\
Governance & 63.54 & 76.79 & 4.17 & 70.83 & 80.36 & 4.17 & 11.50 & 4.60 & 0.00 \\
Employees & 56.94 & 64.29 & 12.50 & 62.50 & 76.19 & 11.11 & 9.70 & 18.50 & -11.10 \\
Customers & 4.17 & 7.14 & 19.44 & 9.72 & 11.90 & 19.44 & 133.10 & 66.60 & 0.00 \\
\hline
\end{tabular}


Table IV.

Aggregate Islamic bank social outcomes (2015-2016)

\begin{tabular}{|c|c|c|c|c|c|c|c|c|}
\hline \multirow[b]{2}{*}{ Bank type } & \multicolumn{2}{|c|}{ Assets (IDR Billion) } & \multicolumn{2}{|c|}{ WA $(\%)$} & \multicolumn{2}{|c|}{$\mathrm{SO}\left(\mathrm{x}_{\mathrm{i}}\right)$} & \multicolumn{2}{|c|}{ SOWA (Rating) } \\
\hline & 2015 & 2016 & 2015 & 2016 & 2015 & 2016 & 2015 & 2016 \\
\hline $12 \mathrm{ICBs}$ & 186,371 & 235,425 & 84.50 & 85.07 & 46.25 & 52.92 & 47.41 & 53.50 \\
\hline 7 IBUs & 32,336 & 39,020 & 14.70 & 14.10 & 55.71 & 58.93 & (D) & (A) \\
\hline 7 IRBs & 1839.8 & 2285 & 0.80 & 0.83 & 18.93 & 21.07 & - & - \\
\hline Total & 220,547 & 276,730 & 100.0 & 100.00 & - & - & - & - \\
\hline
\end{tabular}

Note: WA - weighted assets; SO ( $\mathrm{x} i$ ) represents SO element of $\mathrm{x}_{i}$; SOWA social outcomes weightedasset average. $\mathrm{D}=$ Defensive, $\mathrm{A}=$ Accommodative 